Meталлофиз. новейшие технол. / Metallofiz. Noveishie Tekhnol. (C) 2014 ИМФ (Институт металлофизики 2014 , т. 36, № 4, сс. 551-557

Оттиски доступны непосредственно от издателя

им. Г. В. Курдюмова НАН Украины)

Фотокопирование разрешено только

Напечатано в Украине.

в соответствии с лицензией

PACS numbers: 75.50.Gg, 75.60.Jk, 75.75.Jn, 75.78.Jp, 78.20.Ls, 78.47.J-, 85.75.-d

\title{
Laser-Induced After-Effect in Tunnel Magnetic Nanostructures
}

\author{
M. M. Krupa, V. G. Kostishin*, and A. M. Korostil \\ Institute of Magnetism N.A.S. and M.E.S. of Ukraine, \\ $36^{b}$ Academician Vernadsky Blvd., \\ 03142 Kyiv, Ukraine \\ "National University of Science and Technology 'MISiS', \\ 4 Leninskiy Prospekt, \\ 119049 Moscow, Russia
}

The laser-induced magnetic after-effects in magnetic nanostructures consisting in magnet reversal under ultra-short circularly polarized laser pulses are studied. Using the magneto-optical method and a pump-probe technique based on the Kerr and Faraday effects, features and conditions of magnetic reversal in ferrimagnetic-based nanostructures under femtosecond circularly polarized laser pulses are established. As shown, the mechanisms of such laser-induced impact are a complex process of laser-induced thermal demagnetization of magnetic sublattices with a subsequent magnetic biasing by internal magnetic fields of different nature. Depending on the laser-pulse duration and intensity, they can be effective magnetic fields of laser irradiation or internal magnetic fields conditioned by different rates of the thermal demagnetization of ferrimagnetic sublattices. Features of the laser-induced tunnel magnetoresistance effect in ferrimagnetic junctions are considered.

Досліджено лазерно-індуковані ефекти післядії в магнетних наноструктуpax, які полягають в перемагнетуванні у полі ультракоротких циркулярно поляризованих лазерних імпульсів. 3 використанням магнетооптичної методи накачування-зондування, що грунтується на Керровому та Фарадейовому ефектах, встановлено особливості перемагнетування у феримагнетних наноструктурах під дією фемтосекундних лазерних імпульсів. Показано, що механізми такого лазерно-індукованого впливу є комплексними процесами лазерно-індукованого теплового розмагнетовування феримагнетних підгратниць 3 подальшим підмагнетовуванням внутрішніми ефективними полями різної природи. Залежно від тривалости й інтенсивности лазерних імпульсів, це можуть бути поля лазерного випромінення або внутрішні поля, пов'язані з відмінністю швидкостей теплового розмагнетовування підгратниць. Розглянуто особливості лазерно-індукованого тунельного магнеторезистивного ефекту в феримагнетних переходах. 
Исследованы лазерно-индуцированные эффекты последействия в магнитных наноструктурах, состоящие в перемагничивании в поле ультракоротких циркулярно поляризованных лазерных импульсов. С использованием магнитооптического метода накачки-зондирования, основанного на эффектах Керра и Фарадея, установлены особенности перемагничивания в ферримагнитных наноструктурах под действием фемтосекундных лазерных импульсов. Показано, что механизмы такого лазерно-индуцированного воздействия являются комплексными процессами лазерно-индуцированного теплового размагничивания магнитных подрешёток с последующим подмагничиванием эффективными внутренними полями различной природы. В зависимости от длительности и интенсивности лазерных импульсов это могут быть поля лазерного излучения или внутренние поля, связанные с различием скоростей теплового размагничивания подрешёток. Рассмотрены особенности лазерно-индуцированного туннельного магниторезистивного эффекта в ферримагнитных переходах.

Key words: magnetization dynamics, magnetic reversal, magneto-optical effects, tunnel magnetoresistance effect, ferrimagnetic nanostructures, pulsed laser radiation.

(Received November 25, 2013)

\section{INTRODUCTION}

Physical limits of remagnetization speed are one of fundamental problems of magnetism physics, which has a crucial significance for creation of high-speed magnetic recording and readout systems of information. Growth of attention to this problem is related to modern achievements of nanotechnologies, by possibilities of production of new magnetic nanostructures with predetermined physical properties, and development of the short-time pulsed laser radiation. The prospect of the solution of this problem is related to the use of the impact of short-time laser pulses on the ferrimagnetic multi-layered nanostructures, specifically, tunnel magnetic junctions [1], that can lead to magnetic state variations and the remagnetization effect.

The key role belongs to the effects connected with the lasercontrolled spin manipulation including the spin-polarized electron transport in magnetic nanostructures that constitute the subject of the modern magnetism physics, spintronics, and microelectronics. The laser-induced magnetic transitions in magnetic nanostructures are determined both by their spin and electron structure and by physical characteristics of laser radiation. Corresponding magnetic materials must possess rather high values of magnetic anisotropy, magnetooptical susceptibility, and the spin polarization of conduction electrons. The laser radiation must be characterized by the high degree of polarization, a strong intensity, and its pulse duration must correspond to short times of electron and spin relaxations. 
The fast-speed directed laser magnetic impacts are realized via the laser-induced thermal demagnetization with subsequent remagnetization by effective internal magnetic fields of different nature depending on the magnetic structure of materials and laser radiation characteristics. The effective internal magnetic bias fields can be connected with the inverse magneto-optical Faraday effect (see [1, 2]) and with the effects of the transient ferromagnetic-like state in combination with the relaxation of the exchange antiferromagnetic interaction under the pulsed laser-induced thermal demagnetization [3-5]. In the first case, the bias magnetic field $\left(H_{F}\right)$ arises only under circularly polarized laser irradiation. In the second case, the bias field $\left(H_{T R}\right)$ is the internal transient field caused only by the different speeds of the laserinduced thermal demagnetization, and it is independent on the radiation polarization.

The indirect laser-induced magnetic impact can be realized via the laser-induced spin-polarized electron current [1] caused by banddependent kinetic properties of spin-polarized electrons under their momentum-selective interband laser excitations [6]. Then, the laser magnetic control is realized via the exchange interaction of the spinpolarized electron current with localized magnetic moments of a magnetic nanostructure.

The features and mechanisms of the laser-induced magnetization and remagnetization are considered below in ferrimagnetic-based single layers and multi-layered nanostructures. The role of laser-induced spin-polarized currents in processes of the laser-induced remagnetization is investigated in tunnel magnetic junctions. The laser control of the spin-polarized current in tunnel ferrimagnetic nanostructures via the pulsed laser-induced remagnetization is considered for the case of TbFeCo-based compounds.

\section{DYNAMICS OF MAGNETIZATION SWITCHING}

The influence of femtosecond circularly polarized pulsed laser radiation on magnetic states and the conductance of the spin-polarized electron current is studied for the TbCoFe- and CoFe-based ferrimagnetic nanostructures. Features of the laser-induced magnetization reversal are studied for $\mathrm{Al}_{2} \mathrm{O}_{3} / \mathrm{Tb}_{25} \mathrm{Co}_{5} \mathrm{Fe}_{70} / \mathrm{Al}_{2} \mathrm{O}_{3}, \mathrm{Al}_{2} \mathrm{O}_{3} / \mathrm{Tb}_{22} \mathrm{Co}_{5} \mathrm{Fe}_{73} / \mathrm{Al}_{2} \mathrm{O}_{3}$, $\mathrm{Al}_{2} \mathrm{O}_{3} / \mathrm{Tb}_{19} \mathrm{Co}_{5} \mathrm{Fe}_{76} / \mathrm{Al}_{2} \mathrm{O}_{3}$ and $\mathrm{Al}_{2} \mathrm{O}_{3} / \mathrm{Co}_{30} \mathrm{Fe}_{70} / \mathrm{Al}_{2} \mathrm{O}_{3}$ nanostructures with a single ferrimagnetic nanolayer. The laser-induced magnetic reversal with the laser-induced tunnel magnetoresistance (TMR) effect is studied for ferrimagnetic $\mathrm{Al}_{2} \mathrm{O}_{3} / \mathrm{Tb}_{22} \mathrm{Co}_{5} \mathrm{Fe}_{73} / \mathrm{Pr}_{6} \mathrm{O}_{11} / \mathrm{Tb}_{19} \mathrm{Co}_{5} \mathrm{Fe}_{76} / \mathrm{Al}_{2} \mathrm{O}_{3}$ and $\mathrm{Al}_{2} \mathrm{O}_{3} / \mathrm{Co}_{80} \mathrm{Fe}_{20} / \mathrm{Pr}_{6} \mathrm{O}_{11} / \mathrm{Co}_{30} \mathrm{Fe}_{70} / \mathrm{Al}_{2} \mathrm{O}_{3}$ junctions with the PrO-based isolating barrier nanolayer. The TbCoFe-based and $\mathrm{CoFe}$-based layers are characterized by uniaxial out-plane and in-plane magnetic anisotropy, respectively. 
The laser-induced magnetization dynamics is studied with the help of the magneto-optical pump-probe method based on the magnetooptical Kerr and Faraday effects. The Nd-YAG and He-Ne lasers generated the pulsed pump (with duration $\tau_{i} \cong 130 \mathrm{fs}$ ) and probe radiations. The scheme of corresponding optical research is presented in Fig. 1.

Due to the strong spin-orbital interaction for the rare-earth $\mathrm{Tb}$ atoms, the femtosecond laser-induced magnetization does not cause the magnetic reversal only by the laser-induced heating [4] that is explained by the delay in the dynamics of intersublattice exchange relaxation. The distinction between magnetic moments of atoms $\mathrm{Tb}$ and $\mathrm{Fe}$ results in the distinction of corresponding magnetic moments of $\mathrm{Tb}$ and FeCo sublattices of ferrimagnetics. This is exhibited in the dependence of ferrimagnetic nanolayers on their component composition.

The direct laser impact on the magnetization occurs via the interaction of the circularly polarized photons with spin-polarized electrons of a magnetic medium. The Raman-like photon excitations of the electrons together with a spin-orbital interaction are accompanied by the spin-flip and remagnetization (see [2]) providing the inverse magnetooptical Faraday effect with the effective internal bias field $\left(H_{F}\right)$. The pulsed laser irradiation causes heating and demagnetization that in combination with the laser-induced effective magnetic field can lead to variation of magnetic states and the remagnetization. The direct

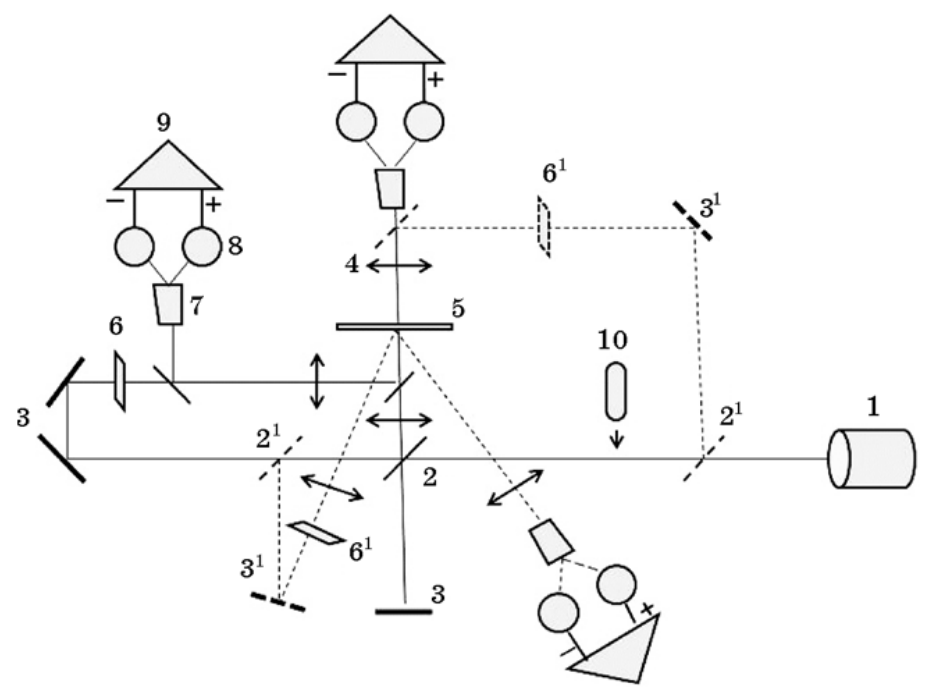

Fig. 1. Experimental scheme of the optical investigation: femtosecond laser$1,50 \%$ mirror - 2, total reflection mirror-3, long-focus lens-4, substrate with film -5 , polarizer -6 , Senarmon prism -7 , photodiode -8 , differential amplifier-9, Babinet compensator-10. 
femtosecond laser-induced impacts can result in the internal effective bias magnetic field $H_{T R}$ connected with the transient ferromagneticlike state caused by different demagnetization rates of ferrimagnetic sublattices [3-5]. However, in the considered case of $\mathrm{TbCoFe}-$ based ferrimagnetic this bias field $H_{T R}$ can play role of amplification of the effective bias field of the inverse magneto-optical Faraday effect. The transient ferromagnetic state is succeeded by the recovery of the magnetization.

The indirect laser impact on magnetic states in nonuniform multilayered magnetic nanostructures occurs via the laser-induced spinpolarized electron current between magnetic nanolayers. In this case, the remagnetization of the magnetic junction can be caused by the exchange $s-d$-interaction of the laser-injected spin-polarized current with the localized magnetic moment of the injected layer of the magnetic junction. The effective internal magnetic field $H_{s d}$ of that interaction consists of two components, $H_{s d}=H_{s}+H_{i n j}$. The first component $H_{s}$ is related to the $s-d$-interaction of the transverse component (with respect to the magnetic moment of the injected layer) of the magnetic moment of the spin-polarized current. The second component $H_{i n j}$ is related to the $s-d$-interaction of the laser-injected longitudinal spin component (with respect to the magnetic moment of the injected layer), which is characterized by a non-equilibrium distribution. The mentioned effective internal magnetic fields together with laserinduced thermal demagnetization result in the remagnetization, which is accompanied by a tunnelling magnetoresistance (TMR) effect.

The results of the magneto-optical measurements are presented in

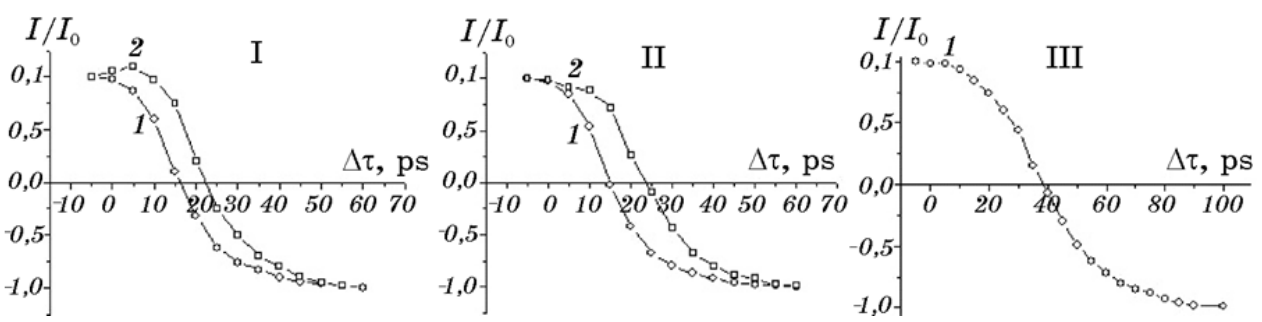

Fig. 2. The time dynamics of the laser-induced remagnetization under the high-power polarized laser pulses. (I) Probe laser pulses pass through the $\mathrm{Al}_{2} \mathrm{O}_{3} / \mathrm{Tb}_{19} \mathrm{Co}_{5} \mathrm{Fe}_{76} / \mathrm{Al}_{2} \mathrm{O}_{3}$ (1) and $\mathrm{Al}_{2} \mathrm{O}_{3} / \mathrm{Tb}_{25} \mathrm{Co}_{5} \mathrm{Fe}_{70} / \mathrm{Al}_{2} \mathrm{O}_{3}$ (2) films irradiated by circularly polarized pulses. (II) The probe laser pulses are reflected from the $\mathrm{Tb}_{19} \mathrm{Co}_{5} \mathrm{Fe}_{76}$ nanolayer of the $\mathrm{Al}_{2} \mathrm{O}_{3} / \mathrm{Tb}_{22} \mathrm{Co}_{5} \mathrm{Fe}_{73} \uparrow / \mathrm{Pr}_{6} \mathrm{O}_{11} / \mathrm{Tb}_{19} \mathrm{Co}_{5} \mathrm{Fe}_{76} \downarrow /$ $\mathrm{Al}_{2} \mathrm{O}_{3}$ junction irradiated from the side of $\mathrm{Tb}_{22} \mathrm{Co}_{5} \mathrm{Fe}_{73}$ nanolayer by circularly (1) and linearly (2) polarized pulses. (III) Probe pulses are reflected from the $\mathrm{Co}_{30} \mathrm{Fe}_{70}$ nanolayer of ferrimagnetic $\mathrm{Al}_{2} \mathrm{O}_{3} / \mathrm{Co}_{80} \mathrm{Fe}_{20} \uparrow / \mathrm{Pr}_{6} \mathrm{O}_{11} / \downarrow \mathrm{Co}_{30} \mathrm{Fe}_{70} / \mathrm{Al}_{2} \mathrm{O}_{3}$ junction irradiated from the side of the $\mathrm{Co}_{80} \mathrm{Fe}_{20}$ nanolayer by the circularly polarized pulses. 
Fig. 2. As it is seen from curves $I$, the laser-induced magnetic reversal of the $\mathrm{Tb}_{19} \mathrm{Co}_{5} \mathrm{Fe}_{76}$ nanolayer under circularly polarized laser pulses occurs faster than magnetic reversal of $\mathrm{Tb}_{25} \mathrm{Co}_{5} \mathrm{Fe}_{70}$ nanolayer because of the different contributions of the iron magnetization in the total magnetic moment of these nanolayers.

As seen from curves II in Fig. 2, the laser-induced magnetic reversal of the ferrimagnetic junction under circularly polarized laser pulses (related to the bias field $H_{F}$ ) is determined by the magnetic reversal of the irradiated ferrimagnetic nanolayer. The laser-induced magnetic reversal under linearly polarized laser pulses is determined by the above-mentioned effective bias field $H_{s d}$ related to the laser-induced spin current. As $H_{F}>H_{s d}$, the remagnetization rate is higher in the case of the circularly polarized laser irradiation.

The behaviour of the laser-induced remagnetization of the CoFebased nanolayer with in-plane magnetic anisotropy is related to the bias field $H_{s d}$. In considered cases, at strong laser-induced heating, bias field $H_{T R}$ can enhance the remagnetization effect.

The above-mentioned laser-induced magnetization in the TbCoFeand CoFe-based ferrimagnetic junction is accompanied by the tunnel magnetoresistance effect, which occurs without an external magnetic field. Corresponding curves of the laser-induced resistance changes under femtosecond circularly polarized laser pulses are presented in
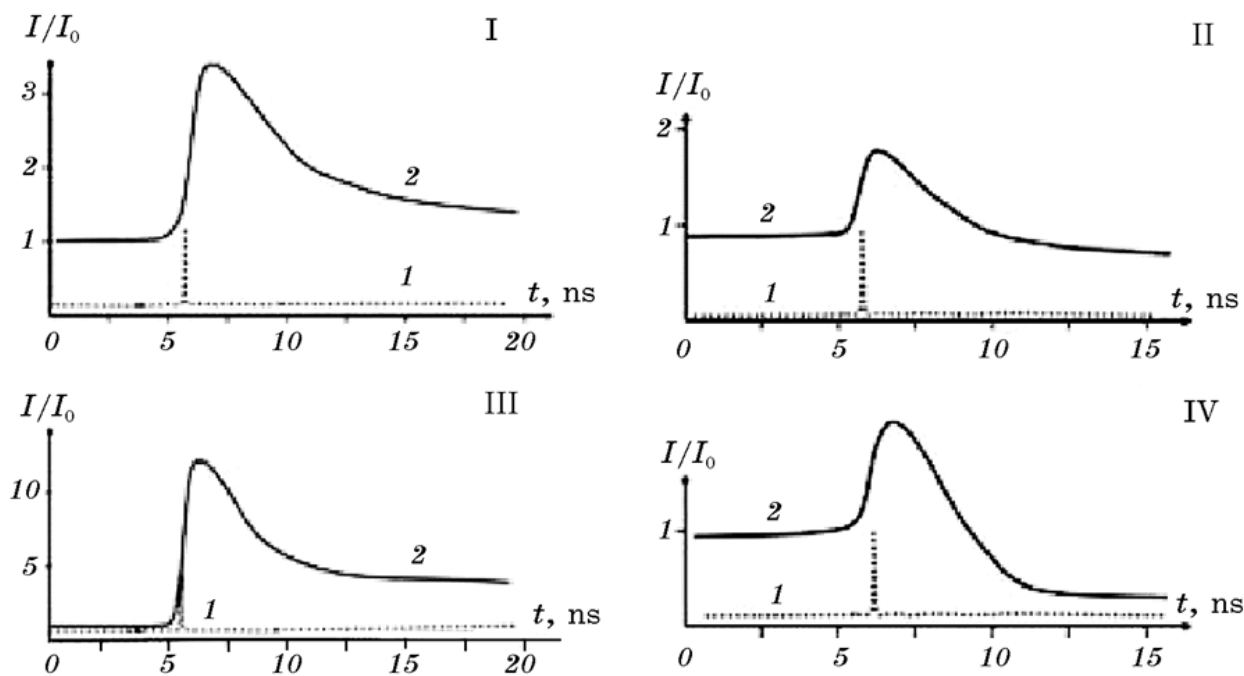

Fig. 3. The laser-induced conductivity dynamics of ferrimagnetic $\mathrm{Tb}_{22} \mathrm{Co}_{5} \mathrm{Fe}_{73} \uparrow /$ $\mathrm{Pr}_{6} \mathrm{O}_{11} / \uparrow \mathrm{Tb}_{19} \mathrm{Co}_{5} \mathrm{Fe}_{76}$ (I, III) and $\mathrm{Co}_{80} \mathrm{Fe}_{20} \uparrow / \mathrm{Pr}_{6} \mathrm{O}_{11} / \downarrow \mathrm{Co}_{30} \mathrm{Fe}_{70}$ (II, IV) junctions irradiated by the circularly polarized femtosecond laser pulses from the side of the layer $\mathrm{Tb}_{22} \mathrm{Co}_{5} \mathrm{Fe}_{73}(\mathrm{I}, \mathrm{II})$ and $\mathrm{Co}_{80} \mathrm{Fe}_{20}$ (II, III), respectively, at $T=300 \mathrm{~K}$ (I, II) and $T=80 \mathrm{~K}$ (III, IV). 
Fig. 3. The laser-induced change of conductivity of the ferrimagnetic tunnel junctions are caused by changes of density of states of spinpolarized electrons near Fermi level caused by the transition between parallel and antiparallel magnetization configuration of the junctions. Generally, for the TbCoFe-based tunnel junction, the remagnetization occurs via the laser-induced effective total internal bias field, $H_{t}=$ $=H_{F}+H_{s d}+H_{T R}$.

For the CoFe-based tunnel magnetic junction with in-plane magnetic anisotropy, the bias field $H_{t}=H_{s d}+H_{T R}$. The value of the TMR effect (presented in Fig. 3) depends on the tunnel conductivity of the PrObased tunnel barrier, which is considerable because of the observable overlap between wave states of electrons outside and inside of the widegap semiconducting tunnel barrier.

\section{REFERENCES}

1. I. Zutic, J. Fabian, and S. Das Sarma, Rev. Mod. Phys., 76, No. 2: 323 (2004).

2. A. Kirilyuk, A. V. Kimel, and T. Rasing, Rev. Mod.Phys., 82, No. 3: 2731 (2010).

3. I. Radu, K. Vahaplar, C. Stamm, T. Kachel, N. Pontius, H. A. Dürr, T. A. Ostler, J. Barker, R. F. L. Evans, R. W. Chantrell, A. Tsukamoto, A. Itoh, A. Kirilyuk, Th. Rasing, and A. V. Kimel, Nature, 472, Iss. 7342: 205 (2011).

4. A. R. Khorsand, M. Savoini, A. Kirilyuk, A. V. Kimel, A. Tsukamoto, A. Itoh, and Th. Rasing, Phys. Rev. Lett., 110, No. 10: 107205-1 (2013).

5. T. A. Ostler, J. Barker, R. F. L. Evans, R.W. Chantrell, U. Atxitia, O. Chubykalo-Fesenko, S. El Moussaoui, L. Le Guyader, E. Mengotti, L. J. Heyderman, F. Nolting, A. Tsukamoto, A. Itoh, D. Afanasiev, B. A. Ivanov, A. M. Kalashnikova, K. Vahaplar, J. Mentink, A. Kirilyuk, Th. Rasing, and A. V. Kimel, Nature Communications, 3, No. 666: 1 (2012).

6. V. M. Shalaev, C. Douketis, J. T. Stuckless, and M. Moskovits, Phys. Rev. B, 53, No. 17: 11388 (1996). 